\title{
Antimicrobial Activity of Water and Methanol Leaf Extracts of Green Tea (Camellia Sinensis) Against Some Pathogenic Bacteria
}

\author{
Shahlaa M. Saleh, Bushra H. Saleh and Enas S. Bahjat A. \\ Department of Biotechnology, College of Science Al-Nahrain University.
}

\begin{abstract}
This study was carried out to investigate the antimicrobial activity of water and methanol leaf extracts of Camillia sinensis against some pathogenic bacteria. Susceptibilities of S. aureus (SR '), $S$. aureus (SR Y), S.typhimurium, E.coli, P. aeruginosa and Proteus to different antibiotics (Ampicillin, Streptomycin, Rifampicin and Neomycin) by disc diffusion test was carried out. Results revealed that $S$. aureus (SR'), S. aureus (SR Y), P.aeruginosa, and S.typhimurium were resistant to Ampicillin and Rifampicin. E. coli was resistant to Ampicillin, Rifampicin and Neomycin while Proteus was resistant to all antibiotics used in this study. Antimicrobial activity of water and methanol leaf extracts of green tea at different concentrations $\left(\Upsilon_{\bullet}, \Sigma_{\bullet}, \tau_{\cdot}, \wedge \cdot\right.$ and $\left.1 \ldots\right)$ $\mathrm{mg} / \mathrm{ml}$ against pathogenic bacteria was tested. Results showed that green tea water and methanol leaf extract showed inhibitory effect against pathogenic bacteria and methanol extract exhibited better antimicrobial effect against Staphylococcus aureus.
\end{abstract}

Keywords: Green tea, antimicrobial activity, methanol extract.

\section{Introduction}

Green tea is a type of tea made solely from the leaves of Camellia sinensis, that has undergone minimal oxidation during processing. Varieties can differ substantially due to variable growing conditions, processing and harvesting time [ ']. The phytochemical screening of tea revealed the presence of alkaloids, saponins, tannins, catechin and polyphenols. The cardinal antioxidative ingredient in the green tea extract is green tea catechins which comprise four major epicatechin derivatives; namely, epicatechin (EC), epigallocatechin (EGC), epicatechingallate (ECG), and

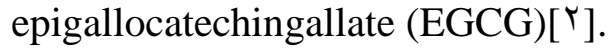

Other components include three kinds of flavonoids, known as kaempferol, quercetin, and myricetin. A remarkably higher content of myricetin which may have some bioactivity against pathogen is detected in tea and its extracts than in many other plants $[r]$. As a result of the growing problem of antibiotic resistant bacteria, studies are now being conducted regarding the antimicrobial effects of compounds found in natural foods, such as green tea [₹]. Green tea has long been valued throughout the world for its therapeutic properties $\left[{ }^{\circ}\right.$ ]. The phytochemical screening of tea revealed the presence of alkaloids, saponins, tanins, catchin and polyphenol [ [ ]. Also studies showed that moderate dialy consumption of green tea killed staphylococcus aureus and other harmful bacteria [ $\mathrm{V}]$. Differences in antimicrobial activities of tea have been found to be related with the kind and degrees of fermentation of tea [^]. Studies found that extracts of tea inhibited and killed Staphylococcus aureus, Staphylococcus epidermidis, Salmonella typhi, Salmonella typhimurium, Salmonella enteritidis, Shigella dysenteriae, Shigella flexneri, and Vibrio spp; including Vibrio cholera. $\left[{ }^{\vee}\right]$.

\section{Materials and Methods \\ Plant material}

The plant was bought from local market. Leaves of (Camellia sinensis) ground into fine powder using grinding machine $\left[{ }^{9}\right]$.

\section{Bacterial isolates}

Bacterial isolates used in this study were supplied by Al- Mustansyria Univ., Biology Dept. Staphylococcus aureus (SR'), Pseudomonas aeruginosa and Proteus were previously isolated from patients with wound infection. Other isolates Staphylococcus aureus (SR r), Salmonella typhimurium and E.coli were previously isolated from patients with burn infection.

\section{Water extracts}

Twenty five grams of the leaf powder were extracted for three hrs in ro. $\mathrm{ml}$ of the distilled water using the soxhlet apparatus and the source of heating was water bath $\left(\mathrm{V} \cdot{ }^{\circ} \mathrm{C}\right)$. The filtrate was then evaporated at $\vee \cdot{ }^{\circ} \mathrm{C}$ using 
a rotary evaporator, and the resultant crude extract was frozen at $-r \cdot{ }^{\circ} \mathrm{C}$ until use to prepare the required concentrations $\left[l^{\bullet}\right]$.

\section{Methanol Extraction}

Twenty five grams of leaf powder were extracted for $T$ hours in $Y 0 . \mathrm{ml}$ of $90 \%$ methanol. The filterate was concentrated using rotary evaporator at $1 \cdots^{\circ} \mathrm{C}$ until dryness [ 11$]$.

\section{Testing susceptibility of isolates to antibiotics}

Disk diffusion test was used for testing susceptibilities of isolates to different antibiotics Ampicillin, Streptomycin, Rifampicin and Neomycin (Oxoid). bacterial isolates were inoculated in ten $\mathrm{ml}$ of nutrient broth medium, the cultures were incubated at $\mathrm{rVC}^{\mathrm{O}}$ to mid log phase 1 hrs. $1 \cdots \mu$ l of inoculated broth then transferred to Muller-Hinton agar plates. A sterile cotton swab was used in three different planes to obtain an even distribution of the inocula for inoculating triplicate plates. With sterile forceps, the selected antibiotic disks were placed on the inoculated plate and incubated the plates at $\mathrm{rV}^{\circ} \mathrm{C}$ for $r \leqslant \mathrm{hrs}$ in an inverted position. Then diameter of inhibition zone were noted and measure by a ruler in $\mathrm{mm}[\mathrm{l} r]$.

\section{Determination of the antimicrobial activity}

Extracts activities were determind against pathogenic bacteria. For dried leaves water and methanol extract, the stock solution was prepared by dissolving $\left({ }^{\circ}\right) \mathrm{g}$ of leaves extract residue with $\left(0^{\circ}\right) \mathrm{ml}$ sterile distilled water then, other concentrations were prepared $\left(r_{\cdot}, \varepsilon \cdot, r_{\cdot}, \wedge \cdot\right.$ and $\left.1 \cdot \cdot\right) \mathrm{mg} / \mathrm{ml}$. The extract solutions were sterilized by filtration using Millipore filter $(\cdot, \leqslant 0) \mu \mathrm{m}$ under aseptic conditions $[\mathrm{I} T$.

The nutrient agar medium was mixed well and $r \cdot m l$ was poured in Petri-dishes. The medium was swabbed with $\cdot, 1 \mathrm{ml}$ of a suspension containing $\left(1,0 \times 1 \cdot 0^{\circ}\right) \mathrm{cfu} / \mathrm{ml}$ of the pathogenic bacteria (S.aureus $(S R$ )), (S.aureus $(S R$ r) S.typhimurium, Ecoli, P.aruginosa, and Proteus).

The well-plate diffusion technique was used. Five plugs were removed from each agar plate using a sterile Pasteur pipette to produce omm-diameter well $[1 \leqslant, 10]$. To each hole,
( $\cdots) \mu l$ from different concentrations of each extract was added and allowed to diffuse at room temperature for $r \cdot \min$ to identify the intrinsic extracts. The plates were incubated aerobically at $r{ }^{\circ} \mathrm{C}$ for $r \leqslant$ hrs. Each extract was tested against each organism in triplicate. The antimicrobial activity of the plant extracts were recorded as the mean diameter of the resulting inhibition zones of growth measured in millimeters.

\section{Results and Discussion}

Results shown in Table (1) indicated that the resistance to antibiotics was varied according to the nature of isolates and kind of antibiotics. E. coli was resistant to Ampicillin, Rifampicin and Neomycin while Proteus was resistant to all antibiotics used in this study. Results showed that $S$. aureus ( $S R$ '), S. aureus $(S R$ r), P.aeruginosa, and S.typhimurium were resistant to Ampicillin and Rifampicin.

Table (')

Susceptibility of bacterial isolates to antibiotics

\begin{tabular}{|c|c|c|c|c|}
\hline \multirow{2}{*}{ Isolates } & \multicolumn{4}{|c|}{ Antibiotics $(\mu \mathrm{g} / \mathrm{ml})$} \\
\hline & $\begin{array}{c}A M \\
\text { ro }\end{array}$ & $\begin{array}{l}S \\
1 .\end{array}$ & $\begin{array}{r}R F \\
1 .\end{array}$ & $\begin{array}{l}N \\
1 .\end{array}$ \\
\hline S. aureus $S R$ ' & $\mathrm{R}$ & $\mathrm{S}$ & $\mathrm{R}$ & $\mathrm{S}$ \\
\hline S. aureus $S R$ r & $\mathrm{R}$ & $\mathrm{S}$ & $\mathrm{R}$ & $\mathrm{S}$ \\
\hline S.typhimurium & $\bar{S}$ & $\bar{S}$ & $\overline{\mathrm{R}}$ & $\bar{S}$ \\
\hline E.coli & $\mathrm{R}$ & $\mathrm{S}$ & $\mathrm{R}$ & $\mathrm{R}$ \\
\hline P. aeruginosa & $\mathrm{R}$ & $\bar{S}$ & $\mathrm{R}$ & $\mathrm{S}$ \\
\hline Proteus & $\overline{\mathrm{R}}$ & $\overline{\mathrm{R}}$ & $\mathrm{R}$ & $\mathrm{R}$ \\
\hline
\end{tabular}

S: Sensitive, R: Resistant.

\section{AM: Ampicillin, S: Streptomycin, RF: Rifampicin, N: Neomycin}

Results in Table ( $($ ) and Fig.( $(1)$ showed that high concentration of green tea water extract ( $\wedge$. and,$\cdots) \mathrm{mg} / \mathrm{ml}$ exhibited an inhibitory effect against pathogenic bacteria according to the zone of inhibition. Maximum inhibition diameter was romm against S.aureus (SR $r$ ) isolated from skin infection and $r r, 1 \wedge, 1 r$ and $1 r \mathrm{~mm}$, followed by $r, r \cdot, I V, I r$ and $1 r \mathrm{~mm}$ against S.aureus $(\mathrm{SR}), 1 \wedge, 1 \mathrm{~V}, 10,1 \cdot$ and $1 \cdot \mathrm{mm}$ against P.aeruginosa, $\mid \wedge, 1 \mathrm{~V}, 10,1 \mathrm{r}$ and $1 . \mathrm{mm}$ against Proteus, 10,1 $1,11,1 \cdot$ and 1.) $\mathrm{mm}$ against S.typhimurium and $11,1 \cdot, 1 \cdot, 11$ and 
Journal of Al-Nahrain University Science

1. against E.coli. This may be due to the ability of water extract to exhibit a wide spectrum inhibition effect against Gram positive and Gram negative bacteria.

\section{Table ( $)$}

Diameter of inhibition zone caused by

Camellia sinensis leaves water extract at various concentrations on some pathogenic bacteria.

\begin{tabular}{|c|c|c|c|c|c|}
\hline \multirow{2}{*}{$\begin{array}{c}\text { Conc. } \\
\text { of the extract } \\
\mathrm{mg} / \mathrm{ml}\end{array}$} & \multicolumn{5}{|c|}{$\begin{array}{c}\text { Diameter of inhibition } \\
\text { zone }(\mathrm{mm}) \\
\end{array}$} \\
\hline & r. & $\varepsilon$. & 7. & $\Lambda$. & $1 \ldots$ \\
\hline S. aureus SR' & $1 \pi$ & 17 & IV & $r$. & rY \\
\hline S. aureus SRT & IT & 17 & 11 & Tr & To \\
\hline S.typhimurium & 1. & 1. & 11 & $\overline{~ I T ~}$ & 10 \\
\hline E.coli & 1 . & 11 & 1 . & 1 . & 11 \\
\hline$P$. aeruginosa & 1. & $1 \cdot$ & 10 & IV & 11 \\
\hline Proteus & 1. & IT & 10 & IV & 11 \\
\hline
\end{tabular}

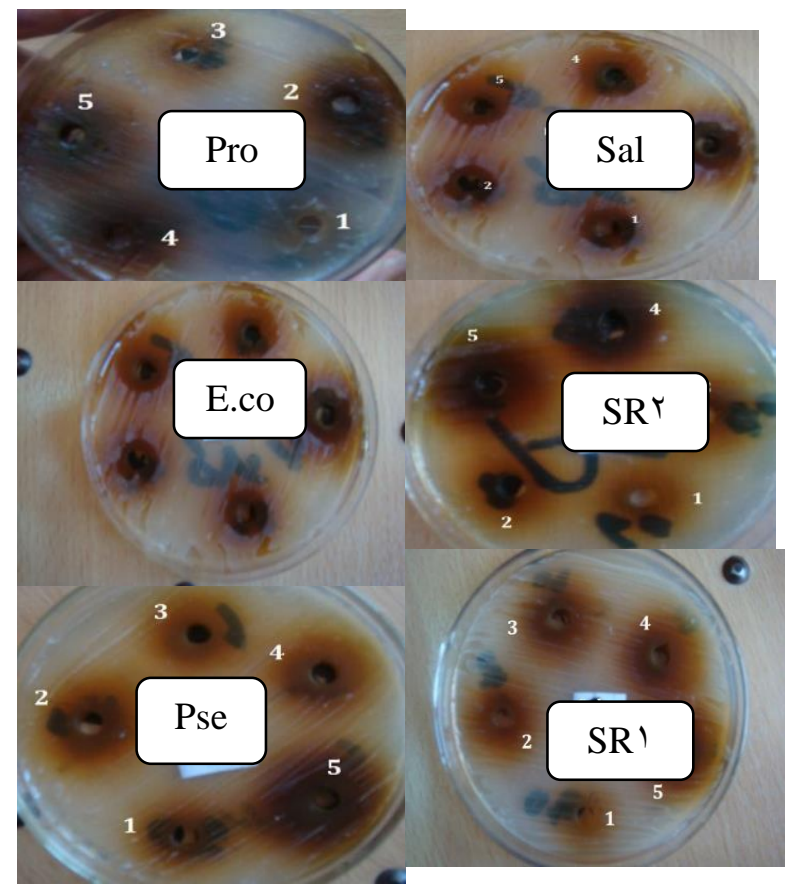

Fig.( 1) Inhibitory effect of Camellia sinensis water leaf extracts against (Staphylococcu aureus $S R$ ', Staphylococcus aureus $S R$ ', Salmonella typhimurium, Pseudomonas aeruginosa, E. coli and proteus) on solid media as demonstrated by the inhibition zones produced wilth the well-diffusion antagonosm method.
Results in Table ( $(r)$ Fig. $(r)$ shown that high concentration of green tea methanolic extract $(\wedge$, and,$\cdots) \mathrm{mg} / \mathrm{ml}$ exhibited the inhibitory effect against pathogenic bacteria according to the zone of inhibition. Maximum inhibition diameter was ( $r \vee \mathrm{mm})$ against (S.aureus $\left(\mathrm{SR}^{\mathrm{r}}\right)$ isolated from skin infection and $\left(r_{\cdot}, r_{\cdot}, \backslash \wedge\right.$ and 10$) \mathrm{mm}$, followed by $(r 0, Y 0, Y r, 19$ and $1 \wedge) \mathrm{mm}$ against (S.aureus (SR'), ( $|\wedge,| \vee, \mid 0,1 \Gamma$ and 11$) \mathrm{mm}$ against (P.aeruginosa), (' $\mathrm{Y}, 11$ and $1 \cdot) \mathrm{mm}$ against (Proteus) $(1 \cdot,) \cdot$ and $1 \cdot) \mathrm{mm}$ (S.typhimurium) and $(1,11,1 \cdot, 1 \cdot$ and $1 \cdot)$ against E.coli.

\section{Table (}

Diameter of inhibition zone caused by Camellia sinensis leaves methanol extract at various concentrations on some pathogenic bacteria.

\begin{tabular}{|c|c|c|c|c|c|}
\hline \multirow{2}{*}{$\begin{array}{c}\text { Conc. } \\
\text { of the extract } \\
\mathrm{mg} / \mathrm{ml}\end{array}$} & \multicolumn{5}{|c|}{$\begin{array}{c}\text { Diameter of inhibition } \\
\text { zone }(\mathrm{mm})\end{array}$} \\
\hline & r. & $\varepsilon$. & 7. & 1. & $1 \ldots$ \\
\hline S. aureus SR I & 11 & 19 & r & ro & ro \\
\hline S. aureus $S R R^{r}$ & 10 & 11 & $r$. & $r$. & rV \\
\hline S.typhimurium & -ve & -ve & 1. & 1. & 1 . \\
\hline E.coli & 1. & 1. & 1. & 11 & 11 \\
\hline P. aeruginosa & 11 & IT & 10 & IV & 11 \\
\hline Proteus & -ve & -ve & 1. & 11 & ir \\
\hline
\end{tabular}

$-v e=$ no activity. 


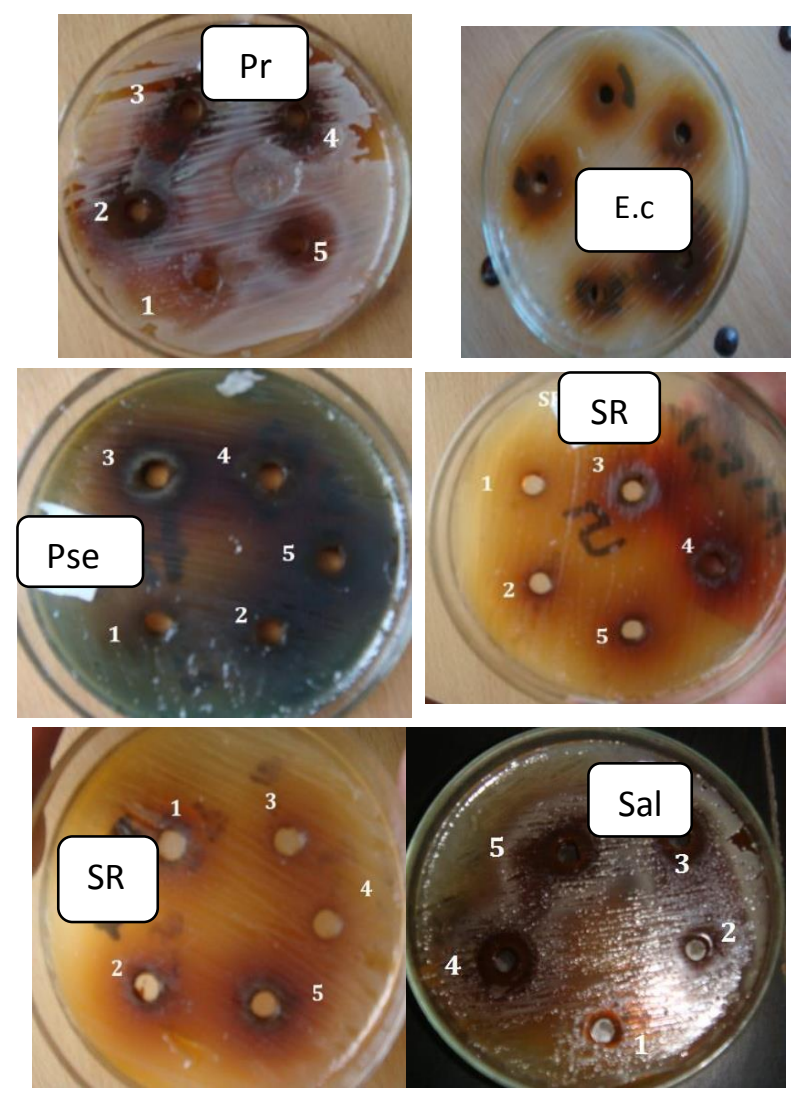

Fig. ( () Inhibitory effect of Camellia sinensis methanolic leaf against (Staphylococcu aureus $S R$ ', Staphylococcus aureus $S R$ ', Salmonella typhimurium, Pseudomonas aeruginosa, E. coli and Proteus) on solid media as demonstrated by the inhibition zones produced wilth the well-diffusion antagonosm method.

This result was agreed with $[\mathrm{V}]$ who reported that daily consumption of green tea can kill Gram positive Staphylococcus aureus and other harmful bacteria. Also it has been reported that the green tea contain catechin and polyphenols. These compounds have been found to possess antibacterial and antiviral action as well as anticarcinogenic and antimutagenic properties.

It was proven that green tea has anticancer and anti hypercholesterole activities, it has also anti bacterial activity that includes inhibition of Gram positive cocci, Gram negative bacilli and resistant strains such as vancomycin-resistant enterococci and methicillin resistant $S$. aureus $[17] .$, as well as multi-drug resistance P. aeruginosa $[1 \mathrm{~V}, 1 \wedge]$.

Various studies have shown significant suppressive effects of green tea against many microorganisms, for example Salmonella typhimurium [19]., Salmonella typhi, Shigella dysenteriae, Yersinia enterocolitica, E. coli, $S$. aureus, Vibrio cholerae, Campylobacter jejuni, Plesiomonasshigelloides, $P$. aeruginosa and many other species of bacteria $[r,, r], r r$ and $r$ r ].

Catechin shows antibacterial activity particularly affecting the membrane fluidity in both, hydrophilic and hydrophobic regions of lipid bilayers of the microorganism. The antibacterial activities of catechins were predominantly related to the gallic acid moiety and the hydroxyl group member $\left[r \leqslant, r_{0}\right]$. The mode of action of catechin involves including rapid leakage of small molecules entrapped in case of intraliposomal space and aggregation of the liposomes have been reported earlier. Catechins also show antibacterial activity by inhibiting the action of DNA polymerases [rT].

However, several high-quality investigations have examined the relationship between flavonoid structure and antibacterial activity and these are in close agreement. In addition, numerous research groups have sought to elucidate the antibacterial mechanisms of action of selected flavonoids. The activity of quercetin, for example, has been at least partially attributed to inhibition of DNA gyrase. It has also been proposed that sophoraflavone $\mathrm{G}$ and (-)-epigallocatechingallate inhibit cytoplasmic membrane function, and that licochalcones $\mathrm{A}$ and $\mathrm{C}$ inhibit energy metabolism [ $r v]$.

\section{References}

['] Sarma DN., Barrett MI. and Chavez ML., "Safety of green tea extracts: a systematic rewiew by the US pharmacopeia. Drug", Saf. ${ }^{\top}(\tau), \leq 7 q_{-} \wedge \leq, r \cdots \wedge$.

$[\ulcorner]$ Golden EB. "Green tea polyphenols block the anticancer effects of bortezomib and other boronic acid-based proteasome inhibitors",

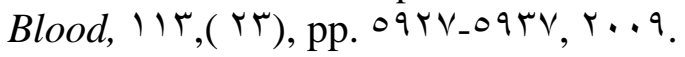

[r] Monobe M., Ema K, Kato F. and MaedaYamamoto M. "Immunostimulating activity of a crude polysaccharide derived from green tea (Camellia sinensis) extract", J. Agric Food Chem, or(₹), $1 \leqslant r r, r \ldots \wedge$.

[₹] Stoicov CS, Saffari RS and Houghton JH. "Green Tea Inhibits Helicobacter Growth in Vivo and In Vitro". International Journal of 
Journal of Al-Nahrain University

Science

Antimicrobial Agents, $r r^{(0)}, \varepsilon \vee r_{-} \varepsilon \vee \wedge$, r.. 9 .

[0] Sharangi AS. "Medicinal and therapeutic potentialities of tea (Camellia sinensis L.) A review". Food Research International. \& r,orq_oro, r... .

[`] Sofowara A. "Medicinal plants and Traditional medicine in Africa". John Wiley Chichester. p. Y07, 19^ะ.

[`] Toda M, Okubo S. and Shimamura T. "Antibacterial and bactericidal activities of Japanese green tea", Jpn. J. Bacteriol; $\leqslant \varepsilon(\varepsilon)$ 779-TVY, 1919.

[^] Chou CL., Lin LL. and Chung KT. "Antimicrobial activity of tea as affected by the degree of fermentation and manufacturing season", Int J Food Microb. $\Sigma \wedge(Y), 1$ Y $\mathcal{O}_{-} \mid r \cdot$, 1999 .

[9] Abu-Shanab B., Adwan G., Abu-Safiya D., Jarrar N. and Adwan K. "Antibacterial activities of some plant extracts utilized in popular medicine in Palestine", Turk. J. Biol., $\left.r \wedge, q_{-}\right) \cdot r, r \ldots \varepsilon$.

[1•] Amra P.U., Mojca, S., and Sabine G. "Extraction of active ingredients from green tea Camellia sinensis" Food chem., 97:09V_ 7.0, Y... .

[1'] Harbone NV. "Phytochemical method. A guide to modern techniques of plant analysis", $r^{\text {nd }}$ ed. Chapman and Hall London. p. $\leqslant$ ro, $199 \leqslant$.

[ $\mathrm{Y}$ ] Atlas R., Park L. and Brown A. "Laborratory manual of experimental microbiology" $\left.\right|^{\text {st }}$ (ed). mospy, IMT missouri. USA. p. or $7,1990$.

[IT] El-Astal Z. Y., Ashour A. and Kerrit A. "Antimicrobial activity of some medicinal plant extracts in Palestine", Pak. J. Med. Sci., $r \backslash(r), \backslash \wedge V_{-} \backslash 9 r, r \ldots 0$.

[ $\left.{ }^{\prime}\right]$ ClarkA. M., El-Feraly F. and Li W. "Antimicrobial activity of phenolic constituents of Magnolia grandiflora L." J. Pharmcol. Sci., V•, 901 r, 1911 .

[10] Shihchih L., Babajide O. and Charles D. "Methoxysampangine, a novel antifungal copyrine alkaloid from Cleistopholis patens" Antimicrob. Agents Chemother., $r \varepsilon(\varepsilon)$, or9_orr, 199.

[17] Hamilton-Miller J. "Antimicrobial properties of tea (Camellia sinensis)", Antimicrob. Agents. Chemother., rq, rrvo-rrvv, 1990.
[ $\mathrm{V}$ ] Lee Y.L., Cesario Y., Wang E. and "Thrupp L. "Antibacterial activity of vegetables and juices", Nutrition, 199 _-997, r..r.

['^] HosseiniJazani N., Shahabi S. and. Abdi Ali A. "Antibacterial effects of water soluble green tea extracts on multi-antibiotic resistant isolates of Pseudomonas aeruginosa", Pak. J. Biol. Sci., 1·, $10 \leqslant \varepsilon_{-} 10 \leqslant 7, Y \cdots \vee$.

[19] Shetty M., Subbannayya K. and Shivananda P.G "Antibacterial activity of tea Camellia sinensis and coffee Coffeearabica with special reference to Salmonella typhimurium", J. Commun. Dis., $Y \tau, 1 \leqslant V_{-} 10 \cdot, 199 \leqslant$.

$[r \cdot]$ Taguri T., Tanaka T. and Kouno I., "Antimicrobial activity of $1 \cdot$ different plant polyphenols against bacteria causing foodborne disease", Biol. Pharm. Bull., rV. 1970_1979. Y... .

[r'] Yam T.S., Hamilton-Miller J.M. and Shah S. "The effect of a component of tea Camellia sinensis on methicillin resistance, $\mathrm{PBP}^{\mathrm{r}}{ }^{\prime}$ synthesis and beta-lactamase production in Staphylococcus aureus". J. Antimicrob. Chemother., \&r, r 1)-r1 1991 .

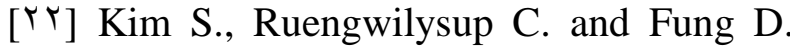
Y., "Antibacterial effect of water-soluble tea extracts on food borne pathogens in laboratory medium and in a food model", J. Food Prot., TV, Y . A_r YIY. Y.. .

$\left[{ }^{r}\right]$ ] Stapleton P.D., Shah S.,. Hamilton-Miller J. M, Hara Y., Nagaoka Y., Kumagai A. and Taylor P.W. "Anti-Staphylococcus aureus activity and oxacillin resistance modulating capacity of r-O-acyl-catechins". Int. J. Antimicrob. Agents., $r \varepsilon, r \vee \varepsilon \_r \wedge \cdot, r \ldots \varepsilon$.

$[r \varepsilon]$ Hironori T. "Effects of green tea catechins on membrane fluidity". Pharmacology, ०१: $r \varepsilon \varepsilon \varepsilon, r \ldots \tau$.

[ro] Nance C.L.,. Williamson M. T., Cormick S. and Shearer S. "Epigallocatechingalate, green tea catechins, binds to the $\mathrm{T}$-cell receptor, $\mathrm{CD} \leqslant "$. J. Allergy clin. Immu, $r \leqslant$ : $11 q_{-} \mid r \leq, Y \cdots 7$.

[Yy] Jane H. "Micronutrient research for optimum health.Tea and Chronic Disease Prevention".http://lpi.oregonstate.edu/nswltr main.html. Y..l.

[YV] T-Cushnie A. W. and Lamb, E. E. "Antimicrobial activity of flavonoids" International Journal of Antimicrobial Agents, r $r, 0, r \leqslant r_{-} r_{0}, 19 \Lambda \Lambda$. 
الخلاصة

اجريت هذه الدراسة لمعرفة الفعالية التثبيطية للمستخلص

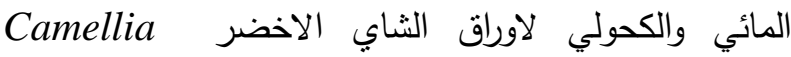
ضinensis العزلات المستخدمة لبعض المضادت الحيوية (الامبيسلين وريفامبيسين وستربتومايسين ونيومايسين) اذ اظهرت النتائج ان لان g. aureus (SR r), , S. aureus (SR )), Sانت مقاومة $\quad$ P.aeruginosa $S$.typhimurium للالامبيسلين و ريفامبيسين و E.coli كانت مقاومة الامبيسلين و ريفامبيسين و نيومايسين اما Proteus فكانت مقاومة للمضادت الاربعة المستخدمة في الدراسة. اما فعالية المستخلص المائي والكحولي لاوراق الثاي الاخضر اظهرت

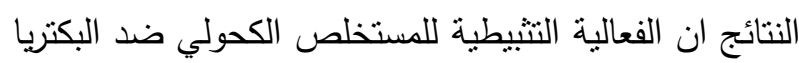
الممرضة كانت افضل من المستخلص المائي. 